\title{
Seasonal Cold-Wave Propagation Into the Near-Surface Ice of Debris-Covered Khumbu Glacier, Nepal
}

\author{
Katie E. Miles ${ }^{1 *}$, Bryn Hubbard ${ }^{1}$, Duncan J. Quincey ${ }^{2}$, Evan S. Miles ${ }^{3}$, Samuel H. Doyle ${ }^{1}$ and \\ Ann V. Rowan ${ }^{4}$ \\ ${ }^{1}$ Centre for Glaciology, Department of Geography and Earth Sciences, Aberystwyth University, Aberystwyth, United Kingdom, \\ ${ }^{2}$ School of Geography, University of Leeds, Leeds, United Kingdom, ${ }^{3}$ Swiss Federal Research Institute WSL, Birmensdorf, \\ Switzerland, ${ }^{4}$ Department of Geography, University of Sheffield, Sheffield, United Kingdom
}

Keywords: debris-covered glacier, ice temperature, Khumbu glacier, Himalaya, near surface, glacier borehole

\section{INTRODUCTION}

OPEN ACCESS

Edited by:

Michael Lehning,

École Polytechnique Fédérale de Lausanne, Switzerland

Reviewed by:

Argha Banerjee, Indian Institute of Science Education and Research, Pune, India

Philip D.A. Kraaijenbrink, Utrecht University, Netherlands

${ }^{*}$ Correspondence: Katie E. Miles kam64@aber.ac.uk

Specialty section: This article was submitted to Cryospheric Sciences, a section of the journal Frontiers in Earth Science

Received: 26 May 2021 Accepted: 03 August 2021 Published: 24 August 2021

Citation:

Miles KE, Hubbard B, Quincey DJ, Miles ES, Doyle SH and Rowan AV (2021) Seasonal Cold-Wave Propagation Into the Near-Surface Ice of Debris-Covered Khumbu

Glacier, Nepal.

Front. Earth Sci. 9:715129.

doi: 10.3389/feart.2021.715129
Meltwater from high-elevation debris-covered glaciers-particularly those located in the greater Himalaya and Andes-shapes the water supply of major rivers and nourishes substantial terrestrial, estuarine, and marine habitats (Kraaijenbrink et al., 2017; Immerzeel et al., 2020). However, the relative inaccessibility and high elevation of such glaciers results in a paucity of data relating to their fundamental physical properties and processes, limiting the information available to constrain and evaluate numerical models of their behaviour and project future change. Knowledge of the subsurface properties of such glaciers is particularly deficient because it is largely obscured to satellite and airborne remote sensing; englacial investigations therefore commonly require direct access (Miles et al., 2020). Of the physical properties of glaciers, ice temperature exerts an important control over glaciological processes, such as glacier motion, and their modelled behaviour. For example, ice viscosity is sensitive to temperature such that, under the same stress, ice approaching the melting point deforms 5-10 times more rapidly than it would at $-10^{\circ} \mathrm{C}$ (Deeley and Woodward, 1908; Cuffey and Paterson, 2010). Basal motion depends on lubrication facilitated by the presence of meltwater at the ice-bed interface and/or within the pore space of a subglacial sediment layer. Measurements of near-surface ice temperatures are important for modelling the surface energy balance and projecting the future mass-balance response of glaciers to anticipated climate change. This is especially the case for glaciers with a thick supraglacial debris layer that insulates the underlying ice (according to debris layer thickness and lithology), reducing ablation and potentially extending glacier longevity (Nicholson and Benn, 2006; Nicholson and Benn, 2013; Anderson and Anderson, 2016).

Here, we present a one-year time series of near-surface ice temperatures, measured between 1.5 and $7.0 \mathrm{~m}$ below the ice surface, in a borehole drilled by hot water into the debris-covered tongue of Khumbu Glacier, Nepal.

\section{METHODS}

\section{Field Site}

Khumbu Glacier is a large debris-covered glacier in the Nepal Himalaya (Figure 1) with a clean-ice accumulation area in the Western Cwm of Mount Everest, from 5,800-8,000 $\mathrm{m}$ a.s.l., where mean annual air temperatures are of the order of -10 to $-20^{\circ} \mathrm{C}$ (Matthews et al., 2020). The supraglacial 


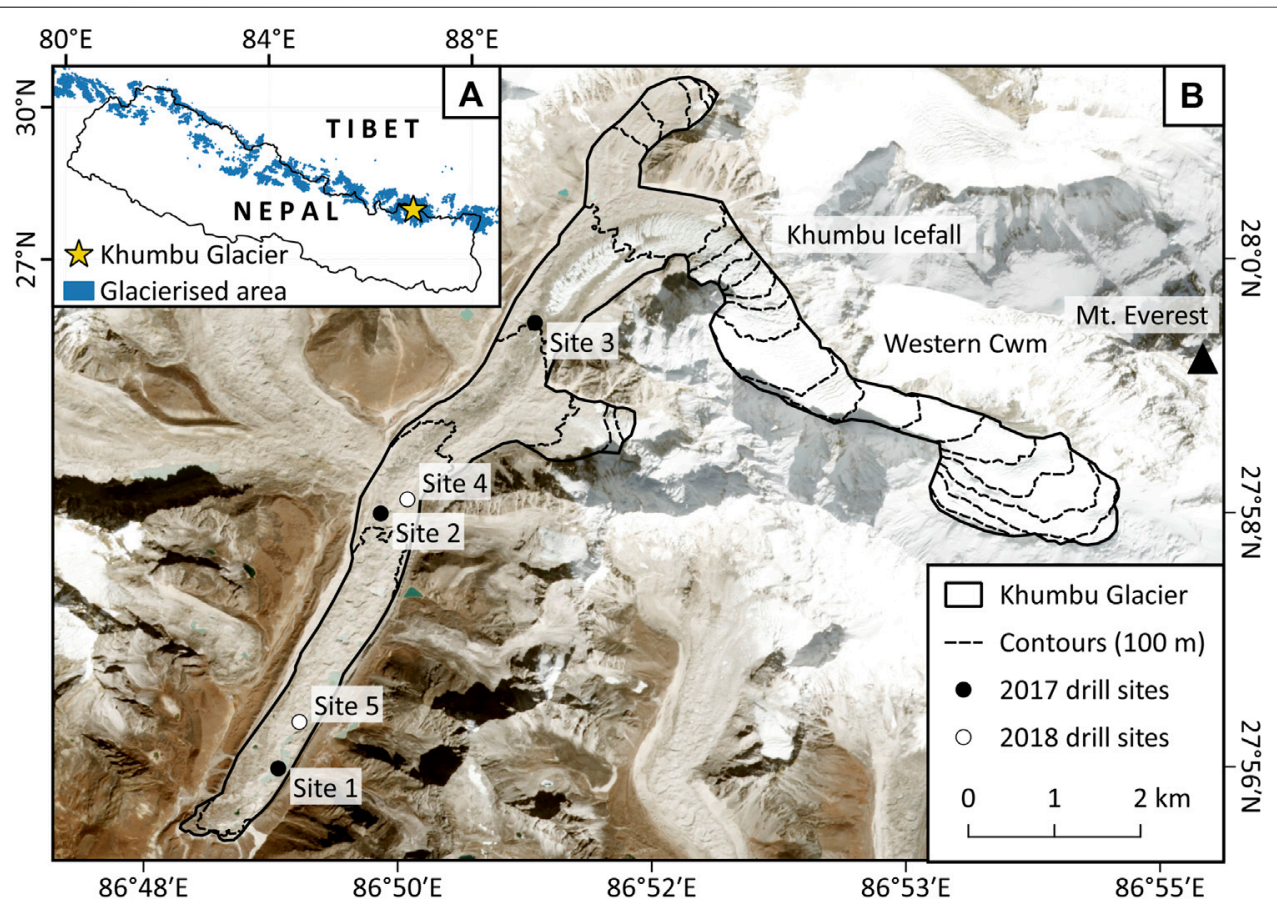

FIGURE 1 | Location of Khumbu Glacier and drill sites. (A) Location of Khumbu Glacier, Nepal. (B) Location of drill sites on the glacier in 2017 and 2018. Background is a Sentinel-2A image acquired on October 30, 2018 (Planet Team, 2017). Glacier contours are at $100 \mathrm{~m}$ intervals from 4,900 to 6,800 m a.s.l., created from the 2015 SETSM DEM (Noh and Howat, 2015).

debris layer begins to form just beyond the base of the Khumbu Icefall at $\sim 5,400 \mathrm{~m}$ elevation, increasing in thickness to several metres at the terminus (Iwata et al., 1980; Miles et al., 2020; Miles et al., 2021). Below the depth of zero annual temperature variation $(\sim 15 \mathrm{~m})$, the glacier is polythermal, based on records from deep thermistor strings across the ablation area (Sites 1-3, Figure 1B) (Miles et al., 2018).

\section{Methods and Data Analysis}

Twenty-seven boreholes were drilled by hot water at five sites across the debris-covered ablation area of Khumbu Glacier in 2017 and 2018 (Miles et al., 2019). Deep ice temperatures were measured at Sites 1-3 (Figure 1B); the first 6 months of measurements between May and October 2017 were reported in Miles et al. (2018). In this data report, we present hitherto unreported shallow ice temperature measurements from Site 4 recorded between May 2018 and May 2019. The temperature data herein were measured by a string of 12 thermistors installed at $0.5 \mathrm{~m}$ depth increments, from 1.5 to $7.0 \mathrm{~m}$, below the ice surface at Site 4 (Figure 1B). Before drilling, supraglacial debris of $\sim 0.6 \mathrm{~m}$ in thickness was removed from an approximately circular area of $\sim 0.5 \mathrm{~m}$ diameter around the borehole location (Miles et al., 2019; Miles et al., 2021). When revisited 1 year later, the borehole was beneath a debris layer that was visually indistinguishable in thickness and character from that more generally present in the area, though the rate of reformation through englacial debris meltout and gravitational processes is not known at this site.

Following Miles et al. (2018), Honeywell UNI-CURVE 192-502LET-AOI thermistors were used to record ice temperatures to an accuracy of $\pm 0.05^{\circ} \mathrm{C}$ at $0^{\circ} \mathrm{C}$ following calibration in a distilled water and ice bath (Iken et al., 1993; Bayley, 2007; Doyle et al., 2018). Thermistor resistance was measured by a Campbell Scientific CR1000 data logger located at the glacier surface, as detailed by Miles et al. (2018). Measurements were made every 10 min between May 5, 2018 and November 14, 2018, and every hour between November 14, 2018, and May 30, 2019 to ensure memory capacity of the data loggers was not exceeded. Resistance was converted to temperature using a Steinhart and Hart (1968) polynomial fitted to the manufacturer's calibration curve, corrected using a freezing-point offset for each individual thermistor obtained from the ice-bath calibration.

\section{CONCLUSION}

The data we present herein comprise a time series of shallow ice temperatures measured between May 2018 and May 2019 at Khumbu Glacier, Nepal. Ice temperatures were recorded simultaneously by 12 thermistors installed at increments of $0.5 \mathrm{~m}$ below the ice surface, from 1.5 to $7.0 \mathrm{~m}$ depth.

The time series (Figure 2) captured the propagation of the cold-season cold wave into the near-surface ice of Khumbu Glacier. The thermistors froze into the borehole within 6 weeks. Beyond the settling curve, the ice temperature increased by $\sim 0.5^{\circ} \mathrm{C}$ through the remainder of the warm season (to November), decreased by several degrees through the cold season, and finally began to warm again into the following warm season. The record quantified three 


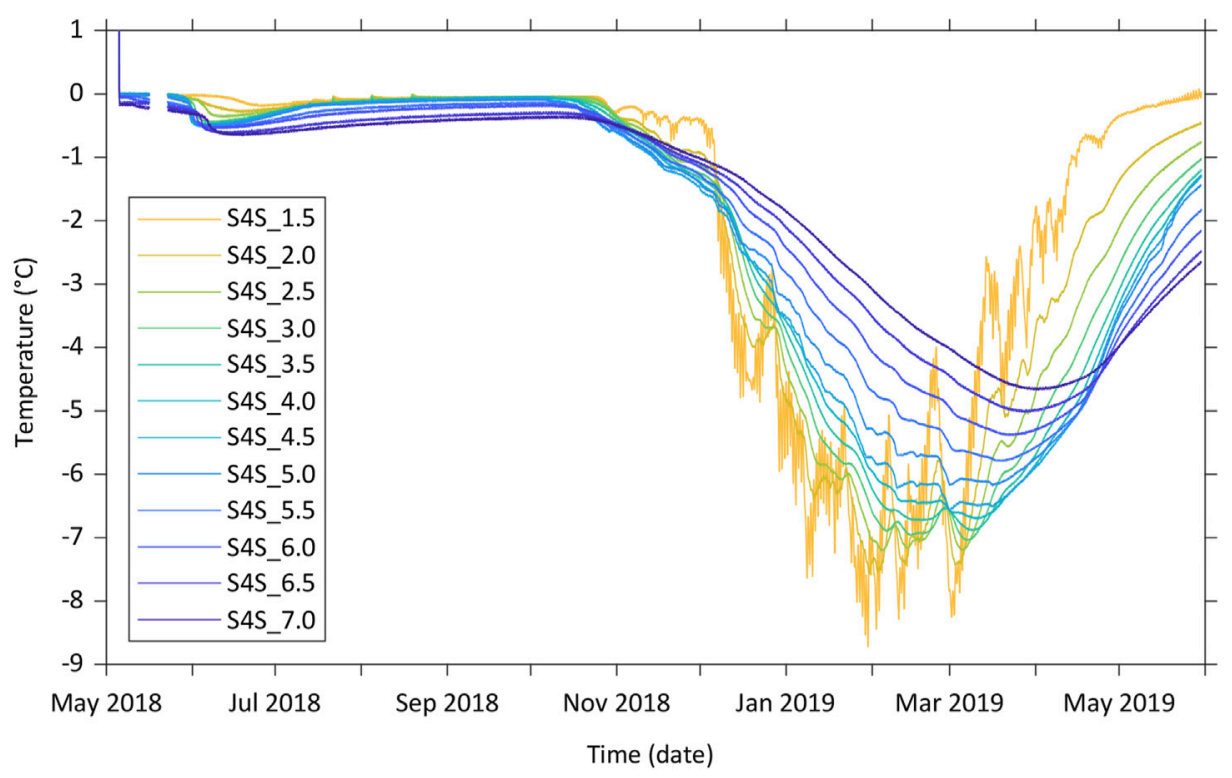

FIGURE 2 | Time series of temperature data measured by the Site 4 shallow-depth thermistor string, colour-coded by thermistor depth. Our thermistor naming convention (e.g., S4S_1.5) is comprised of the borehole site (here, "S4S" refers to "Site 4 shallow"), followed by the depth (in metres) of each thermistor below the surface (here, $1.5 \mathrm{~m}$ ).

anticipated effects as the cold wave propagated to depth: 1) it was delayed, 2) its amplitude decreased, and 3) its high-frequency elements were progressively filtered out. Using daily mean values through the full cold season, the relationship between the rate of change of temperature and second derivative of temperature change with depth (Cuffey and Paterson, 2010) yielded a material thermal diffusivity of $1.1 \mathrm{~m}^{2} \mathrm{~s}^{-1}$, and hence a thermal conductivity of $2.1 \mathrm{~m}^{-1} \mathrm{~K}^{-1}$. These values are typical of glacier ice close to its melting point (Cuffey and Paterson, 2010).

The dataset could be relevant to:

- Comparing shallow englacial temperatures, and interannual variability in them, with air temperatures from AWS data (e.g., Sherpa et al., 2017).

- Investigating near-surface ice mechanics and fracture (e.g., Podolskiy et al., 2018) and constraining thermo-mechanical models of glacier ice deformation (e.g., Gilbert et al., 2020).

- Investigating englacial liquid water availability and microbiology (e.g., Hotaling et al., 2017).

- Extending models of energy transfer through supraglacial debris into the underlying ice (e.g., Nicholson and Benn, 2006; Evatt et al., 2015), possibly including known debris temperature gradients (e.g., Rowan et al., 2021).

- Estimating the timing of the onset and end of the ablation season.

- Estimating the shallow ice temperature gradient along the glacier, and thus its equilibrium line altitude.

\section{DATA AVAILABILITY STATEMENT}

The datasets presented in this study can be found in online repositories. The names of the repository/repositories and accession number(s) can be found below: https://doi.org/10. 6084/m9.figshare.14673837.

\section{AUTHOR CONTRIBUTIONS}

$\mathrm{DQ}, \mathrm{AR}$, and $\mathrm{BH}$ led the EverDrill research project. $\mathrm{KM}, \mathrm{BH}$, and SD designed and assembled the thermistor strings. KM, DQ, EM, $\mathrm{BH}$, and $\mathrm{AR}$ participated in the fieldwork, including borehole drilling and thermistor string installation. KM led manuscript writing, to which $\mathrm{BH}, \mathrm{DQ}, \mathrm{EM}, \mathrm{AR}$, and SD contributed.

\section{FUNDING}

This research was supported by the "EverDrill" Natural Environment Research Council Grant awarded to the Universities of Leeds, Sheffield (NE/P00265X) and Aberystwyth (NE/P002021). Support for equipment also came from HEFCW Capital Equipment Grant awarded to $\mathrm{BH}$ at Aberystwyth University. KM was funded by an Aberystwyth University AberDoc PhD Scholarship.

\section{ACKNOWLEDGMENTS}

We thank Himalayan Research Expeditions for organising logistics and fieldwork permits, and Mahesh Magar for invaluable assistance in the field. We also thank Emily Potter, Tenzing Chogyal Sherpa, and Dawa Tshering Sherpa, who provided support during drilling. We gratefully acknowledge the Sagarmatha National Park authorities for their assistance in granting access and permits. 


\section{REFERENCES}

Anderson, L. S., and Anderson, R. S. (2016). Modeling Debris-Covered Glaciers: Response to Steady Debris Deposition. The Cryosphere 10, 1105-1124. doi:10.5194/tc-10-1105-2016

Bayley, O. D. R. (2007). Temperature of a "Temperate" alpine Glacier. [PhD Thesis]. Switzerland: Glacier de Tsanfleuron.

Cuffey, K., and Paterson, W. S. B. (2010). The Physics of Glaciers. 4th edition. Burlington, MA, USA: Butterworth-Heinemann.

Deeley, R. M., and Woodward, H. (1908). The Viscosity of Ice. Proc. R. Soc. Lond. Ser. A. 81, 250-259.

Doyle, S. H., Hubbard, B., Christoffersen, P., Young, T. J., Hofstede, C., Bougamont, M., et al. (2018). Physical Conditions of Fast Glacier Flow: 1. Measurements from Boreholes Drilled to the Bed of Store Glacier, West Greenland. J. Geophys. Res. Earth Surf. 123, 324-348. doi:10.1002/2017JF004529

Evatt, G. W., Abrahams, I. D., Heil, M., Mayer, C., Kingslake, J., Mitchell, S. L., et al. (2015). Glacial Melt under a Porous Debris Layer. J. Glaciol. 61, 825-836. doi:10.3189/2015JoG14J235

Gilbert, A., Sinisalo, A., Gurung, T. R., Fujita, K., Maharjan, S. B., Sherpa, T. C., et al. (2020). The Influence of Water Percolation through Crevasses on the thermal Regime of a Himalayan Mountain Glacier. The Cryosphere 14, 1273-1288. doi:10.5194/tc-14-1273-2020

Hotaling, S., Hood, E., and Hamilton, T. L. (2017). Microbial Ecology of Mountain Glacier Ecosystems: Biodiversity, Ecological Connections and Implications of a Warming Climate. Environ. Microbiol. 19, 2935-2948. doi:10.1111/1462-2920.13766

Iken, A., Echelmeyer, K. A., Harrison, W., and Funk, M. (1993). Mechanisms of Fast Flow in Jakobshavns Isbræ, West Greenland: Part I. Measurements of Temperature and Water Level in Deep Boreholes. J. Glaciol. 39, 15-25. doi:10.1017/S0022143000015689

Immerzeel, W. W., Lutz, A. F., Andrade, M., Bahl, A., Biemans, H., Bolch, T., et al. (2020). Importance and Vulnerability of the World's Water Towers. Nature 577, 364-369. doi:10.1038/s41586-019-1822-y

Iwata, S., Watanabe, O., and Fushimi, H. (1980). Surface Morphology in the Ablation Area of the Khumbu Glacier. J. Jpn. Soc. Snow Ice 41, 9-17. doi:10.5331/seppyo.41.Special_9

Kraaijenbrink, P. D. A., Bierkens, M. F. P., Lutz, A. F., and Immerzeel, W. W. (2017). Impact of a Global Temperature Rise of 1.5 Degrees Celsius on Asia's Glaciers. Nature 549, 257-260. doi:10.1038/nature23878

Matthews, T., Perry, L. B., Koch, I., Aryal, D., Khadka, A., Shrestha, D., et al. (2020). Going to Extremes: Installing the World's Highest Weather Stations on Mount Everest. Am. Meteorol. Soc. 101, E1870-E1890. doi:10.1175/BAMS-D-190198.1

Miles, K. E., Hubbard, B., Irvine-Fynn, T. D. L., Miles, E. S., Quincey, D. J., and Rowan, A. V. (2020). Hydrology of Debris-Covered Glaciers in High Mountain Asia. Earth-Science Rev. 207, 103212. doi:10.1016/j.earscirev.2020.103212

Miles, K. E., Hubbard, B., Miles, E. S., Quincey, D. J., Rowan, A. V., Kirkbride, M., et al. (2021). Continuous Borehole Optical Televiewing Reveals Variable Englacial Debris Concentrations at Khumbu Glacier, Nepal. Commun. Earth Environ. 2, 1-9. doi:10.1038/s43247-020-00070-x

Miles, K. E., Hubbard, B., Quincey, D. J., Miles, E. S., Sherpa, T. C., Rowan, A. V., et al. (2018). Polythermal Structure of a Himalayan Debris-Covered Glacier
Revealed by Borehole Thermometry. Sci. Rep. 8, 1-9. doi:10.1038/s41598-01834327-5

Miles, K. E., Miles, E. S., Hubbard, B., Quincey, D. J., Rowan, A. V., and Pallett, M. (2019). Instruments and Methods: Hot-Water Borehole Drilling at a HighElevation Debris-Covered Glacier. J. Glaciol. 65, 822-832. doi:10.1017/ jog.2019.49

Nicholson, L., and Benn, D. I. (2006). Calculating Ice Melt beneath a Debris Layer Using Meteorological Data. J. Glaciol. 52, 463-470. doi:10.3189/ 172756506781828584

Nicholson, L., and Benn, D. I. (2013). Properties of Natural Supraglacial Debris in Relation to Modelling Sub-debris Ice Ablation. Earth Surf. Process. Landforms 38, 490-501. doi:10.1002/esp.3299

Noh, M.-J., and Howat, I. M. (2015). Automated Stereo-Photogrammetric DEM Generation at High Latitudes: Surface Extraction with TIN-Based Search-Space Minimization (SETSM) Validation and Demonstration over Glaciated Regions. GIScience \& Remote Sensing 52, 198-217. doi:10.1080/15481603.2015.1008621

Planet Team (2017). "Planet Application Program Interface," in Space for Life on Earth (San Fr. CA). Available at: https://api.planet.com.

Podolskiy, E. A., Fujita, K., Sunako, S., Tsushima, A., and Kayastha, R. B. (2018). Nocturnal Thermal Fracturing of a Himalayan Debris-Covered Glacier Revealed by Ambient Seismic Noise. Geophys. Res. Lett. 45, 9699-9709. doi:10.1029/2018GL079653

Rowan, A. V., Nicholson, L. I., Quincey, D. J., Gibson, M. J., Irvine-Fynn, T. D. L., Watson, C. S., et al. (2021). Seasonally Stable Temperature Gradients through Supraglacial Debris in the Everest Region of Nepal, Central Himalaya. J. Glaciol. 67, 170-181. doi:10.1017/jog.2020.100

Sherpa, S. F., Wagnon, P., Brun, F., Berthier, E., Vincent, C., Lejeune, Y., et al. (2017). Contrasted Surface Mass Balances of Debris-free Glaciers Observed between the Southern and the Inner Parts of the Everest Region (2007-15). J. Glaciol. 63, 637-651. doi:10.1017/jog.2017.30

Steinhart, J. S., and Hart, S. R. (1968). Calibration Curves for Thermistors. Deep Sea Res. Oceanographic Abstr. 15, 497-503. doi:10.1016/0011-7471(68)90057-0

Conflict of Interest: The authors declare that the research was conducted in the absence of any commercial or financial relationships that could be construed as a potential conflict of interest.

The reviewer $\mathrm{AB}$ is currently organizing a Research Topic with one author DJQ

Publisher's Note: All claims expressed in this article are solely those of the authors and do not necessarily represent those of their affiliated organizations, or those of the publisher, the editors and the reviewers. Any product that may be evaluated in this article, or claim that may be made by its manufacturer, is not guaranteed or endorsed by the publisher.

Copyright (c) 2021 Miles, Hubbard, Quincey, Miles, Doyle and Rowan. This is an open-access article distributed under the terms of the Creative Commons Attribution License (CC BY). The use, distribution or reproduction in other forums is permitted, provided the original author(s) and the copyright owner(s) are credited and that the original publication in this journal is cited, in accordance with accepted academic practice. No use, distribution or reproduction is permitted which does not comply with these terms. 